\title{
Architecture_MPS
}

\section{Housing Statements - Perspectives on the Housing Crisis in the UK}

Graham Cairns ${ }^{1,{ }^{*}}$, Ken Loach ${ }^{2}$, Brian Schubert ${ }^{3}$, Rachel Hartley ${ }^{3}$, Colin Rice ${ }^{4}$, Rob MacDonald ${ }^{5}$, Suzanne Muna ${ }^{6}$, Paul Kershaw ${ }^{6}$, Arti Dillon ${ }^{6}$, Elaine Bailey ${ }^{7}$, Glyn Robbins ${ }^{8}$, Eileen Short ${ }^{8,9}$, Rico Wojtulewicz ${ }^{10}$, Campbell Robb ${ }^{11}$, Marianne Fallon ${ }^{12}$, Siân Errington ${ }^{13}$, Stewart Baseley ${ }^{14}$

How to cite: Cairns, G., Loach, K., Schubert, B., Hartley, R., Rice, C., MacDonald, R., Muna, S., Kershaw, P., Dillon, A., Bailey, E., Robbins, G., Short, E., Wojtulewicz, R., Robb, C., Fallon, M., Errington, S., Baseley, S. 'Housing Statements -

Perspectives on the Housing Crisis in the UK.' Architecture_MPS, 2015, 7(1): 2, pp. 1-27. DOI: https://doi.org/10.14324/111.444.amps.2015v7i2.001.

Published: 01 April 2015

\section{Peer Review:}

This article has been peer reviewed through the journal's standard Editorial double blind peer review.

\section{Copyright:}

(C) 2015, The Author(s). This is an Open Access article distributed under the terms of the Creative Commons Attribution License (CC-BY) 3.0 https://creativecommons.org/licenses/by/3.0/, which permits re-use, distribution and reproduction in any medium, provided the original author and source are credited • DOI: https://doi.org/10.14324/111.444.amps.2015v7i2.001

\section{Open Access:}

Architecture_MPS is a peer-reviewed open access journal.

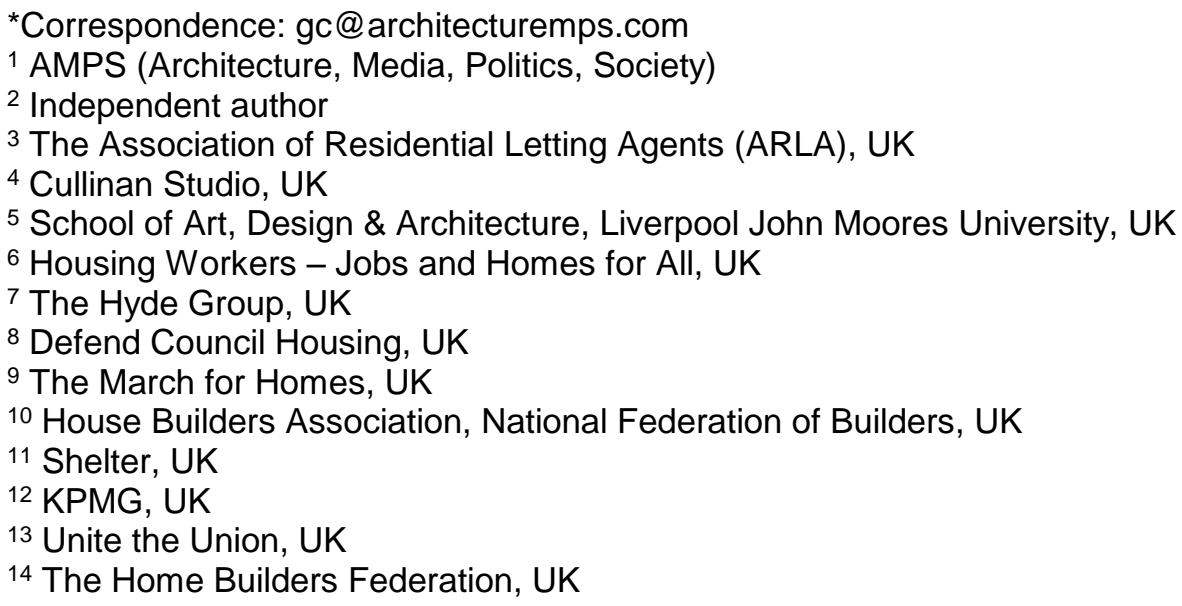




\title{
Special Edition Title: Housing Statements - Perspectives on the Housing Crisis in the UK
}

\author{
Various Authors
}

Architecture_media_politics_society. vol. 7, no.2.

April 2015

Affiliation: Various

\begin{abstract}
:
To coincide with the launch of its conference series as part of the "Housing - Critical Futures" programme, in April 2015, Architecture_MPS invited leading organisations, activists, architects and charities to author opinion pieces on the housing crisis in the UK. Their statements collected together in this special edition. Speakers at the conference included Stephen Hodder, President, RIBA and David Waterhouse, Head of Strategic Planning, CABE. The authors collected together in this issue include: Ken Loach, Film Director; Stewart Baseley, Executive Chairman. The Home Builders Federation; Siân Errington from Unite the Union; Rico Wojtulewicz. Policy Advisor, The House Builders Association; Brian Schubert and Rachel Hartley, The Association of Residential Letting Agents; Colin Rice, Cullinan Studio; Dr Glyn Robbins, Defend Council Housing; Suzanne Muna, Paul Kershaw, Arti Dillon, Housing Workers; Elaine Bailey, Chief Executive, The Hyde Group Housing Association; Eileen Short, Coorganiser The March for Homes; Dr. Rob MacDonald, Academic, Author, Editor, DIY City.
\end{abstract}

These authors represent a diverse range of views on the issue of affordable housing provision in the UK and their essays are each a reflection of a very distinct analysis. From the arguments of those representing volume house builders and those of Housing Associations to the views of architects at leading UK practices known for their work in the field. Also represented are the voices of charities such as Shelter and academics who have spent their careers promoting resident participation in housing. To these voices we add those of trade unions and pressure groups arguing for a continuation of state involvement in the construction and management of the country's housing stock. This diversity is of course deliberate. It is a reflection of the complexity of the issue faced and the diversity of opinions it raises. These essays range from short statements of opinion to manifestos; from calls to action to more extensive pieces of analysis. Coming from people at the heart of the debate in the UK they are a snapshot of the current situation. 


\title{
Special Edition Title: Affordable Housing: An Economic Perspective
}

\author{
Authors: Various
}

Architecture_media_politics_society. vol.7, no.2。

April 2015

\section{$--$}

\section{Introduction:}

To coincide with the launch of its conference series as part of the "Housing - Critical Futures" programme, in April 2015, Architecture_MPS invited leading organisations, activists, architects and charities to author opinion pieces on the housing crisis in the UK. Their statements collected together in this special edition. Speakers at the conference included Stephen Hodder, President, RIBA and David Waterhouse, Head of Strategic Planning, CABE. The authors collected together in this issue include: Ken Loach, Film Director; Stewart Baseley, Executive Chairman. The Home Builders Federation; Siân Errington from Unite the Union; Rico Wojtulewicz. Policy Advisor, The House Builders Association; Brian Schubert and Rachel Hartley, The Association of Residential Letting Agents; Colin Rice, Cullinan Studio; Dr Glyn Robbins, Defend Council Housing; Suzanne Muna, Paul Kershaw, Arti Dillon, Housing Workers; Elaine Bailey, Chief Executive, The Hyde Group Housing Association; Eileen Short, Co-organiser The March for Homes; Dr. Rob MacDonald, Academic, Author, Editor, DIY City.

These authors represent a diverse range of views on the issue of affordable housing provision in the UK and their essays are each a reflection of a very distinct analysis. From the arguments of those representing volume house builders and those of Housing Associations to the views of architects at leading UK practices known for their work in the field. Also represented are the voices of charities such as Shelter and academics who have spent their careers promoting resident participation in housing. To these voices we add those of trade unions and pressure groups arguing for a continuation of state involvement in the construction and management of the country's housing stock. This diversity is of course deliberate. It is a reflection of the complexity of the issue faced and the diversity of opinions it raises. These essays range from short statements of opinion to manifestos; from calls to action to more extensive pieces of analysis. Coming from people at the heart of the debate in the UK they are a snapshot of the current situation. 


\title{
Statement One
}

\section{Title: Collectivity - a political solution to the affordable housing problem}

\author{
Author: Ken Loach, Film Director.
}

Poor housing and homelessness are a continuing disaster: those without a home include ninety three thousand children, nearly sixty thousand families with over a million and a half families on council waiting lists. We should not be surprised. In a market economy, it is not need that drives the building of homes but private profit. That system may work for the big building contractors but it certainly doesn't work for the vast majority of people. Dwellings are now not seen primarily as homes for people but as investments. You can't afford one? Too bad, join the queue for rented accommodation. Rents too high? Tough. Get out of London or squash in with friends or family.

After the war we thought differently. Planners, architects and building contractors were employed directly by local authorities. There was a plan. Good homes, employment, schools, transport, hospitals and green spaces were seen as essential, not luxuries. Housing was a collective responsibility not a market opportunity for business to exploit. That is a humane and civilised way to build a society. We should return to it - and avoid the mistakes that were made later. The Thatcherite, New Labour approach of breaking up established communities has been a predictable disaster, based as it was on the perception that greed was good and that avarice was the motor that would drive us to a more prosperous future. What liars and scoundrels those politicians were! A change is needed.

But when we think about building affordable homes there is another issue we should think about. It is not only a question of housing numbers, house prices, breaking or making communities, healthier habitation and more, there are also questions to be asked with regard those employed in building these homes. The rights of workers in a construction industry led by profit are key concerns. The conditions for building workers have deteriorated greatly over recent decades; people are blacklisted with police connivance for Trade Union activity and never work again; workers are exploited by endless sub-contracting pushing down wages and increasing job insecurity; and, in addition, construction sites continue to be dangerous places to work on.

Furthermore, there are many building workers among the unemployed. Young people could train with proper apprenticeships and could help build the homes of the future. When we think about affordable housing we should not do it in isolation. Affordability can't be allowed to result in more profit, lower wages and poorer working conditions. It is a question of justice and rights on multiple levels. Let's get back to a planned economy, directly employed labour and collectively solve these complex and integrated problems. We know we can do it and we have done it before - all we need is the political leadership to carry it through. 


\section{Amps}

\section{Statement Two}

\section{Title: Lack of Supply Continues to be the Root Cause of Affordable Housing Issues}

Author: Brian Schubert / Rachel Hartley. The Association of Residential Letting Agents (ARLA)

We need more homes. For every house built in the UK currently, two households are created. The facts show that private developers have not met the demand for housing over the last thirty years. We need central and local Government to respond to the needs of the population, ensure that stability allows for skilled workers and house building materials to be in place, and to lead a stable and sustainable programme of house building. We also need to make better use of our current housing stock by encouraging home owners to bring properties left empty for long periods back into use, allowing local authorities to fine home owners that do not.

ARLA urge Government to resist calls to commit tenants to compulsory three year leases. While this may suit some tenants, it will not suit many groups, including a large number of students and those moving for work, who need flexibility. In the private rented sector we need a sensible tax system which allows landlords to refresh their portfolios without massive and punitive taxation penalties. Landlords should be encouraged to provide accommodation which meets the needs of the local market rather than trying to convert existing, inappropriate dwellings while the costs of improvements, maintenance and repairs should be offset against income tax rather than Capital Gains Tax.

Reasonable fees charged by letting agents to tenants are necessary to cover essential costs but these should always be transparent and offer value for money. We have produced The ARLA Student Guide to Renting a House - How to Protect Yourself and Your Money to help students to find first accommodation which is appropriate for them, and to take precautions which allow them to live safely and securely.

By far the biggest problem is a largely unregulated market. ARLA and The National Association of Estate Agents (NAEA) know from working daily with agents, tenants and landlords that most consumers and landlords do not realise that the industry is unregulated. This gives consumers and landlords a false sense of security and means that they do not realise when comparing costs that they are not comparing 'like with like'.

The unregulated market facilitates scurrilous agents to run substandard and hazardous properties. Agents which offer higher standards of service choose to be part of a selfregulatory organisation like ARLA and NAEA, this means that they are expected to maintain standards throughout their properties, and the way that they treat deposit and rent payments is regularly monitored by the association. Rogue agents often cause tenants high levels of stress and loss of money, and many rogue agents are involved in criminal activity.

For years Government have been trying to find legislative solutions to individual issues rather than looking to solve the root cause of the problem. This is evident in areas including immigration, tenancy deposit protection, and energy efficiency, with bills in the pipeline to legislate for smoke and carbon monoxide alarms. This additional piecemeal regulation 


\section{Amps}

increases costs, which in turns pushes rent up and yet unprofessional landlords and agents do not comply and flout the law while local authorities lack the resources to enforce.

By getting rid of additional and unnecessary bureaucracy and creating a simple regulatory model for the sector, the costs of compliance will go down, reducing the need for rent increases and allowing local enforcing bodies to concentrate on the criminal landlords who make life miserable for vulnerable tenants.

The ARLA (the Association of residential Letting Agents) is a UK professional and regulatory body for letting agents. It represents over 7,500 members and campaigns Government for greater regulation in the property market. In 2009 it introduced a licensing scheme to ensure its members are professionally qualified, governed by a strict Code of Practice and offer a complaints and disciplinary procedure so that any disputes are dealt with transparently and fairly.

The NAEA (the National Association of Estate Agents) is a UK professional body for estate agency personnel. It represents over 7,000 members. Its aim is to reassure the general public that by appointing an NAEA member to represent them, they will receive in return the highest level of integrity and service for all property matters. 


\title{
Statement Three
}

\section{Title: Affordable Housing}

\author{
Author: Colin Rice, Cullinan Studio
}

The abuse of words contributes to our cynicism of politics. 'Affordable Housing' is a prime example. To a Martian, affordable would mean ... well, affordable: something I can pay for in my financial circumstances. In our land of double-speak, 'Affordable Housing' is a technical term with other meanings. Typically, if you were seeking Affordable Housing in London it would not be affordable unless you had well above average income.

However, for a healthy city, we need a range of housing so that there are really affordable places to live for all its citizens, and to do that there needs to be greater intervention by our elected government to curb speculation in land and to plan its use better. Since 2011 the Government's new definition of 'affordable rent' means it is set at no more than $80 \%$ of market rent. The Guardian, on the 3rd of February 2015, pointed out that to be able to pay an 'affordable rent' at this level in Westminster, tenants would need an income of up to $£ 109,000$. London employees' median income in 2014 was $£ 34,320$.

The London Plan defines Affordable Housing as 'housing designed to meet the needs of households whose incomes are not sufficient to allow them to access decent and appropriate housing in their borough. Affordable Housing comprises social and intermediate housing.' Clear? This definition starts with 'designed' as if there is some simple connection between design and affordability. There is a role for good design, but it is squeezed by land speculation.

The diagram in KPMG and Shelter's report shows the components that make up the price of housing. 'The residual land value model of bringing land into the system, means that high density development with the lowest possible affordable housing and infrastructure provision is systematically prioritised, with windfall gains for land owners.' In plain English, the key element that affects the price of developer-led housing, and therefore its affordability, is land. Unless this aspect is tackled the only way that housing will become more affordable is by reducing the other variables, in particular build quality - and that includes sustainability and design quality.

Land prices are set through competition to squeeze other costs: KPMG and Shelter.

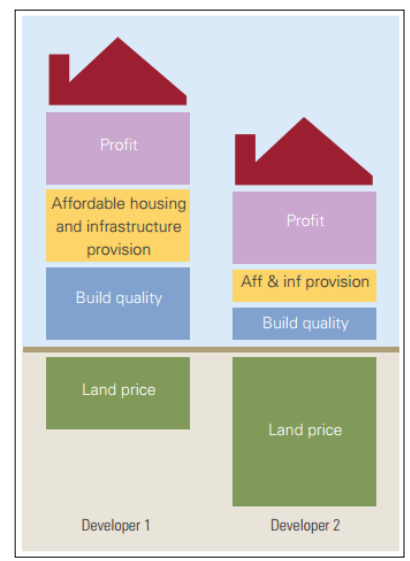


We have to look at housing in a different way. The value of land and the building on it should be separated. The increase in value of the land should accrue to the community as a whole rather than to the private individual.

Present systems to make housing affordable (such as housing benefit, Help to Buy) add fuel to the fire rather than douse its flames. Housing benefit is being used to transfer wealth to landowners at the general taxpayers' expense. The press portrays housing benefit as if the money is going into the pockets of the tenants. Whilst they benefit from the housing, the financial benefit goes to the landlord and the landlord, like any owner of property, is also enjoying substantial capital gain whilst house prices are rising. There must be a better way.

Some possible methods to address this - each the subject of a far longer study - include:

- Introduce Land Value Taxation so that the increase in value of the underlying land is captured for public benefit and recycled to invest in the infrastructure that contributes to that value. This was the economic model of Ebenezer Howard's Garden Cities, and was successfully implemented in the post-war New Towns. Government invested in infrastructure to enable development and, through the rents on that developed land, had a return on that investment.

- $\quad$ Bring in capital gains tax on first and well as second homes.

- $\quad$ Land already held by public authorities is used for housing on a different model. Rather than being sold off to the highest developer bidder, the public authority could retain ownership of the land, extracting rents. This model has served the 'Great Estates' well, giving much of central London its wonderful urban quality that has proved adaptable over several centuries.

Numbers are important but we need to focus on making places - truly sustainable communities - that come from a response to the specific site. The recent introduction of 'Housing zones' could take us back to the 1960s when numbers and method took priority over place-making and build quality. By focusing on numbers we are in danger of repeating the mistakes of the 1960s and 70s when poor quality housing was put up in forms that were not sustainable. The result: the current demolition of developments such as the Aylesbury Estate in Southwark where the council is still paying off the debt on its original construction.

Public investment to produce affordable housing will only work over a long time-frame, using forms of dwelling that will be adaptable and stand the test of time, including climate and social change. We need to design thinking in terms of 200 years timespans. The pattern of terraced streets and squares from $18 \mathrm{C}$ and $19 \mathrm{C}$ proves it is possible.

Homes for the city's citizens will always form the largest portion of the urban matrix. Any old city map shows how this was created in the past: landowners selling off or leasing their fields and providing serviced sites to small and medium housebuilders so that every piece of land is accounted for. In today's terms, such an approach would accommodate development plots for custom builders and self-builders.

Positive master-planning and investment by the public sector must create the physical and organisational framework for a wide range and scales of interventions from the private sector that puts the flesh on the city's bones. The public sector should make a long-term investment for a long-term steady return. Why does all this matter? Because, if cities are to function well, 


\section{Amps}

add to the sum of human happiness and facilitate sustainable wealth creation rather than polarise prosperity, we need housing that is affordable for all citizens of the city.

Text written by: Colin Rice. Cullinan Studio. March 2015

Ed Cullinan is currently a visiting Professor at the University of Nottingham, and has been awarded four other professorships at The Bartlett, Sheffield University, Massachusetts Institute of Technology and Edinburgh University. Cullinan Studio was established in 1965 and has has specialised in design socially responsible, sustainable design. Amongst its housing projects are Bristol Harbourside Building 3b and Penarth Heights Regeneration. It has also enaged in events such as Too few units, even fewer homes!, aimed at raising awareness of the affordable housing crisis. 


\title{
Amps
}

\section{Statement Four}

\section{Title: DIY and Affordability}

\author{
Author: Dr. Rob MacDonald: Academic, Author, Editor. DIY City
}

It seems blatantly obvious, but Affordable Housing needs to be affordable! I want to suggest that if its design and construction remains in the hands of professionals, it may never be so. We need to be more DIY. In the UK young people cannot afford the first rung of the housing ladder and the traditional mortgage is beyond reach - but it is not just an issue for young people or those who seek to buy. Achieving affordability is a complex function of low cost finance, land values, availability and architectural systems and solutions. We need to radicalise the whole system of housing production to generate long life, loose fit and low cost dwelling support systems if the political ambition of building 2-300,000 dwellings per year in the United Kingdom is to be achieved.

It is not a simple process. Design and construction methods may need to be completely upturned. Emphasis ought to be on the reuse of brownfield inner city sites and not building on existing existing green parks and lungs. The procurement methods of public finance, private building and third way collaborative approaches need to be organised around similar coordinated development methodologies. New and old ideas need to be tried and retried. We would do well to remember John Turner's arguments in "Housing is a Verb" when he highlighted that making and inhabiting dwellings is a process. A professor with experience in Third World housing John Turner has written extensively on housing and community organisation. He was influenced by a formative period spent working in the squatter settlements of Peru from 1957-1965. What he identifies is that for many people in the world houses are not objects they buy- they build them piecemeal. Housing is not a noun, it's a verb.

We should also rediscover and apply the theories of Nicholas Harbracken and his "Support Systems" and Low Cost Site and Service projects as developed in the third world. For Harbracken the success of mass (and affordable housing) come from the integration of users and residents into the design process. Walter Segal's system is also one we can also still learn from. Low cost and flexible and adaptable. The Segal self-build method is based on timber frame methods modified to use standard materials all readily available today. It eliminates the need for wet trades, is light-weight and was intended to be built by residents themselves. Central to these approaches of the past, and clearly needed in the present, is the Philosophy of DIY, as in "DIY integrated Cities". While the solution to the housing crisis is complex and beyond the capacity of one person or group to solve we would be well served in looking at those who see the solution close to home - in our own hands. Why do so few self-build projects contribute to the UK's housing stock, why are there so few community led design and build projects today? These initiatives have existed and thrived before. They continue to do so in other countries. In the UK, and the western world more generally, we need a new ideological framework within which to tackle this problem - one that takes responsibility out of the hands of professionals and empowers local residents to do it themselves. 


\section{Statement Five}

\section{Title: Housing Workers Manifesto}

Author: Suzanne Muna, Paul Kershaw, Arti Dillon: Housing Workers - Jobs and Homes for All

Unite believes that housing is a human right. But ordinary people are being forced out of their communities by high prices and speculation. Social housing stock is declining. Over the life of this Parliament homelessness figures have accelerated - the number of people sleeping rough in London for the first time has increased by $17 \%$ in the last year alone. Evictions have also reached the highest rate since records began. No wonder three quarters of the population say there is a housing crisis. Are politicians prepared to take the steps necessary to address this crisis? Unite LE1111 represents housing workers mainly across London but also in some cases nationally - we want politicians to stand for policies that could resolve the situation. Unite recognises that the private sector cannot build affordable homes for working people in the number required. House prices have risen by $50 \%$ over the last five years and home ownership has moved out of reach for many. Instead of cuts we need public sector investment in new council house building on a massive scale as well as an upgrading of the existing housing stock. We demand:

No more cuts! A massive injection of public investment into a council house building programme.

The current government cut social housing grant by $60 \%$ in its first budget and local govt spending has fallen by over 34\% in the life of the Parliament with bigger cuts to areas such as housing welfare support and planning. Ending austerity and cuts is crucial to solving the housing crisis. We call on councillors to resist austerity - Unite is committed to support Labour councillors who vote against cuts.

Build Council houses. Local Authorities to be required to provide and maintain adequate levels of council housing at affordable rents Decent social housing should be an option available to all workers - not just people in the most desperate need. There should be an end to the transfer of council stock to housing associations. Over the last decade 8,000 social homes have been lost through 'estate regeneration' schemes - and more are planned. Build \& repair over 300,000 council homes per year, incorporating improved accessibility and environmental standards.

End the Blacklist. Restrict the commissioning of social housing construction and maintenance services to providers who have signed up to the Joint Industry Board National Agreement for the Engineering Construction Industry. Act to remove from the list of approved providers any social housing or construction company found guilty of blacklisting.

An End to the 'Right to Buy' scheme which only serves to remove homes from the council stock. The speed at which social rented homes are being lost in England more than doubled in the year to April 2014 as right-tobuy sales and a move to more expensive rents took almost 44,000 properties from the sector. 


\section{Amps}

An End to the commercialisation of housing associations. Social housing providers should be accountable to local communities not big business or property developers. We support local accountability and properly resourced regulation. We oppose plans to 'privatise' associations recently advocated in the recent Policy Exchange report.

Rent controls. The Margaret Thatcher government ended rent control for new tenancies although the mechanism of rent tribunals still exists for older private tenancies. The Thatcher legislation must go and all private tenancies should be subject to rent control. 'Generation Rent' calculate that private landlords benefit from subsidies worth the equivalent of $£ 1,000$ for every household in the country - totalling $£ 32.7$ billion.

Establish a National Register of private sector landlords. There should be a national register, with robust regulation, to protesct tenants. However councils can act now using existing powers. Nearly one third of privately rented homes have major safety hazards - those dangerous enough to present a severe threat to the health or safety of a tenant.

Security of tenure for all those living in rented accommodation. The Thatcher government ended secure tenancies in the private rented sector. This legislation must also go and fully secure tenure brought back for private tenants; families can't plan their lives with short term tenancies.

End unfair housing benefit caps and other benefits cuts such as the Bedroom Tax.

Protect supported housing Stop cuts and bring back the ring fence for these services which are vital for some of the most in need of specialist support. They also help reduce pressure on NHS services. Restore and increase the Independent Living Fund for disabled people.

Decent pay and conditions for workers in housing and social care. Employers should agree sector standards with Unite to protect pay and conditions and to ensure proper training organisations getting public money should not be allowed to exploit their workers. Decent conditions for workers are essential for good services. Require all providers to pay a minimun of $£ 10 \mathrm{ph}$.

Nationalise the banks. Unite supports a nationalised banking sector to finance socially necessary projects such as decent housing; the madness of casino banking and deregulated finance has created the crisis. Banks have been bailed out and we have been made to pay the price. Corruption scandals continue to demonstrate the crying need for change. Taking over the banks on a permanent basis would enable investment to be planned in line with democratically decided priorities including housing that working people can afford. We must put a stop to the disaster of austerity and build secure homes for the $99 \%$. 


\section{Amps}

\section{Statement Six}

\section{Title: The Housing Crisis - the view of an Innovative Housing Association.}

Author: Elaine Bailey, Chief Executive, The Hyde Group. Housing Association

Housing has been too far down the agenda for too long, yet it impacts every single person.

The Hyde Group supports the National Housing Federation's call for 'an end to the housing crisis within a generation' and supports the whole industry in coming together to put this message to politicians to tackle the issue head on.

We recognise the urgent need for more housing in the UK, particularly across key areas in the South East and plan to deliver 5000 homes by 2017 to residents of varying tenure to support this need. We believe that the answer to delivering more homes, particularly ones that are affordable or are available for low cost home ownership, is to look for innovative solutions to increase housing capacity across the UK. Hyde works collaboratively with local authorities, setting up a partnership approach which allows local authorities to match their assets with our experience of mixed tenure development and regeneration, to create housing and communities in the most cost-effective and sustainable way.

Now, more than ever before, it is crucial that social housing providers work closer with local authorities to help them unlock the potential in their housing stock in the most cost-effective way. A continuing decline in levels of house building, combined with increased demand, particularly within London and the south east of England, has driven up housing costs significantly and impacted on local communities. Taking a more collaborative approach allows local authorities to tap into social housing providers' financial strength and commercial acumen. Not only does this deliver more affordable homes, it also generates increased revenue for local authorities as well as the other, longer term, benefits regeneration brings to local economies.

Meeting Hyde's commitment to tackle the housing shortage by developing 1,500+ mixed tenure homes a year, delivering quality management services and maximising life chances for residents, would be helped greatly through working with local authority partners to "identify, assess and deliver regeneration that will enhance places and spaces for communities".

The successful regeneration of Packington Estate in Islington and Bermondsey Square in south east London, have demonstrated to Hyde that developing commercially-viable mixed tenure sites through joint ventures with local authorities is a particularly effective way of working. However, there is also the requirement to be flexible and explore innovative approaches alongside traditional joint venture models to ensure local needs are met. For example, on some schemes, Hyde has developed and sold the commercial elements, while the local authority has developed and retained some or all of the affordable homes. We have also acted as sales agents on behalf of our local authority partners. 


\section{Amps}

We are keen to explore all opportunities to boost the much needed supply of new homes and believe that increasing the supply of all tenures is a key factor in helping to overcome the current affordability crisis in London, the South East, and across the country.

\footnotetext{
The Hyde Group:

Provider of the Year - National Housing Awards 2013

Hyde is one of the largest housing associations working in England, owning or managing circa 50,000 homes in London, Kent, Surrey, Sussex, Hampshire, the East of England and East Midlands.

Hyde Plus, Hyde's social investment team, provides advice and support to 3,740 residents. Together with Hyde's Benefit Support team, it secures benefit entitlements and additional income for residents many of whom are affected by the Welfare Reform changes. In addition it helps households to downsize, ensuring residents live in a home they can afford, whilst releasing spare bedrooms. It also offers employment, work placements and training to residents. It is a member of G15 - Housing 1 in 10 Londoners.
} 


\title{
Statement Seven
}

\section{Title: Council Housing Past, Present and Future}

\author{
Author Dr Glyn Robbins, Defend Council Housing.
}

Several events were held across London on Valentine's Day 2015 under the heading 'We Love Council Housing'. In Bethnal Green people met at the Boundary Estate, the birthplace of British council housing and joined a guided tour through 150 years of housing and architectural history that considered the past, present and future of UK housing policy.

The Boundary is a monument to the enduring legacy of public housing investment and the ability of concerted political intervention to relieve a housing crisis. The conditions of the Victorian slums, like the Nichol rookery that stood on the site of today's Boundary, compelled action. The fledgling London County Council's 'Housing of the Working Classes' department, under the visionary leadership of architect Owen Flemming, set new aesthetic standards. The meticulously designed estate of 23 individually-styled tenement blocks, completed in 1900, provided homes for 5,500 people alongside shops, public baths, workshops and laundries - a genuine 'mixed use' development. In 2006, the forces of privatisation circling around council housing tried to entice tenants to transfer the estate to a housing association, but this was overwhelmingly rejected. As a result, the Boundary stands as a publically-owned firebreak against the rampaging, speculative east London property market.

Round the corner in Columbia Road is Leopold Buildings, testament to a very different housing policy tradition. Built in 1872, the ornate façade conceals a more insidious agenda. The block was built by the Improved Industrial Dwellings Company, one of the philanthropic organisations that evolved into housing associations. This was housing provision based not on entitlement, but charity. However, the relatively modest returns of the Victorian 'Five Percenters' are dwarfed by the bank balances of today's commercially oriented, but reputedly non-profit 'Registered Providers' (RPs) such as the Peabody Trust which completed its first block just down the road in Commercial Street in 1862. Today Peabody has a stock of 28,000, a portfolio of commercial property and various trading arms. Although the majority of their homes are for 'social rent', an increasing proportion are of other types, including housing for sale and let as misnamed Affordable Rents at up to 80\% of the market level. Its 2013 annual accounts showed an 'operating surplus' from its rented homes of $£ 35$ million and reserves of $£ 290$ million. Peabody’s chief executive receives a salary of $£ 200,000$, typical of the inflated pay for bosses of 'social' landlords.

Proceeding east along Columbia Road we find 19-storey Sivill House and the 265-home Dorset Estate, designed with love by Skinner, Bailey and Lubetkin and products of the literal and figurative high watermark of council housing. Between 1951 and 1964 at least 100,000 municipal homes were built a year - under a Tory government! But it was the aim of 'more houses more quickly', allied to the unscrupulous role of some private builders that led to the denigration of council housing, particularly after the partial collapse of Ronan Point in 1968.

However, the shifting perspectives of high-rise are illustrated a bit further along Old Bethnal Green Road by Keeling House. Designed by Dennis Lasdun and completed in 1957, Keeling was the first listed municipal tower block, but Lasdun's hope of recreating the communal 


\section{Amps}

qualities of traditional streets was undermined by structural defects. By the early 1990s, Keeling stood empty and symbolised 'everything wrong with doctrinaire post-war planning' ('The Independent' 27th Jan 1993). This facile judgment is contradicted by Keeling's current status. The block was needlessly given away to a private developer by the Council in 1998 and is now marketed as luxury accommodation where a two-bedroom flat costs $£ 500,000+$ to buy, or $£ 2,000$ a month to rent - a grotesque demonstration of the over-heated housing market that is destabilising and distorting urban areas by making them impossible to live in by people with low or medium incomes.

Across the road though is another reminder that there is an alternative to the impotence of current housing policy and the anarchy and waste of the market. The Minerva Estate, built by the Borough of Bethnal Green, was part of the post-war house building programme that saw one million homes built in five years - $80 \%$ of them council homes - amidst the social and economic wreckage of war. The Architectural Journal of the time commented with wonder:

'Every flat has a dresser, a broom cupboard, fuel storage bunker and is fitted with wardrobe cupboards in every bedroom. There is a solid fuel fire in the living room and gas or electric fires in the main bedroom.'

The Minerva used recycled concrete to reduce costs and innovative design to optimise space, but was also part of a philosophy that sought to do more than just build homes, eloquently expressed by Aneurin Bevan:

'We should try to introduce in our modern villages and towns what was always the lovely feature of English and Welsh villages, where the doctor, the grocer, the butcher and the farm labourer all lived in the same street. I believe that is essential for the full life of a citizen... to see the living tapestry of a mixed community. '

This short 'walk' illustrates that arguments for and against council housing are not architectural or technical, but ideological and political. The incremental stigmatisation of and under-investment in public housing obscures the fact that in the 1970 s, $30 \%$ of us were council tenants and $50 \%$ of completions were by local authorities. Since then, house building has reduced by two-thirds, councils have been virtually eliminated as providers of new homes and RPs have utterly failed to fill the gap.

As in the Victorian and post-war eras, we have an acute housing crisis. The solution cannot be found via the untrammelled market or attempts to mediate it through 'the third way'. Defend Council Housing argues the only way out is to rediscover the best traditions of public intervention, but learn the lessons of the past, and produce a new generation of well-designed, energy efficient, secure, affordable, publically-owned council homes. We can't afford not to. 


\section{Statement Eight}

\section{Title: The March for Homes}

Author: Eileen Short, Chair of Defend Council Housing / Co-orgainser The March for Homes

On 31 January 2015, over 5,000 people from across the capital marched on London's City Hall to demand solutions to the housing crisis and better housing for all.

The March for Homes was initiated by Defend Council Housing and the South London Peoples Assembly. It drew wide support from tenant groups, trade unions and housing campaigns and was led by grassroots campaigns. This marks the emergence of a new housing movement, uniting council and private tenants, squatter and homeless campaigns, Bargee Travellers, housing workers and many others. A radical force is beginning to actively challenge political policies causing soaring rents, loss of social housing and rising homelessness. With confidence raised by the 'Focus E15' and 'New Era 4 All' campaigns, more people are challenging the writ of landlords and the threat of eviction, with protests and direct action.

The March made, and continues to make, seven clear demands for action to end the housing crisis:

$\begin{array}{ll}- & \text { Rent controls } \\ - & \text { Cut rents, not benefits } \\ \text { - } & \text { Scrap the Bedroom Tax and Benefit Cap } \\ \text { - } & \text { Affordable and secure homes for all } \\ \text { - } & \text { Stop demolishing quality council homes and build new council houses } \\ \text { - } & \text { Better pay \& conditions for housing workers: better housing services } \\ & \text { Stop scapegoating immigrants and end discriminatory immigration checks for tenants }\end{array}$

Participants in the March for Homes were and are overwhelmingly young and militant. The under-40s have joined the poor, sick and disabled in the firing line of the Coalition Government's war on tenants. A new generation, often renting ex-council flats at exhorbitant rents, are joining council tenants to champion the idea of public investment in a new generation of council housing as an alternative to market-led crisis.

Our experience of building the March was that people had been waiting for this - they often said so! In the January event, two sections, from South and East London, converged, with perfect timing, at Tower Bridge, and marched to the headquarters of London's Mayor and Assembly. Another section of the March went directly to the Aylesbury estate in South London where an occupation continues against plans to

demolish another 2,400 council homes. Since then a week of action and two further occupations, in South and West London, are hardening the cutting edge of the fight for homes. A March for Aylesbury on the 14th of March is a further step in keeping a collective front to our many battles, and building the mass support we need to challenge the current political orthodoxy on housing. 


\section{Amps}

Government, the Mayor of London and too many Councils, tell us developers must be allowed to build for market sale and rent on public land, and that this is the only way to finance any improvement of existing and new council or housing association homes. The public is are all too aware that this is a Con. In fact it means social cleansing, evictions and increasing numbers in private renting paying more for less. For many the only question is, what's the alternative?

In Britain we now pay more for housing, as a proportion of our income, than at any time. Housing has become a means of increasing inequality. So it's not good enough to call for 'more house building'. The question is what homes, who for, and at what cost? Luxury homes often sit empty and bring in more profit for their backers than investments in industry or even in bonds and shares. Those behind these projects are often non-UK citizens but the problem is not the nationality of the investors - it's their profiteering. The blight of empty homes and insecure private renting destroys communities, driving life from neighbourhoods.

And politicians are colluding to encourage this process. Almost the first act of the Coalition Government was to cut $60 \%$ from council/housing association capital investment, followed by attacks on tenancies, rents and benefits. The Bedroom Tax, benefit caps - with rents of up to $80 \%$ market value replacing council rents - and demolition of council estates are all policies driven by Government. In his foreword to a Saville's Report, part funded by Government, Communities Minister and Cabinet member Eric Pickles describes council housing as 'brownfield estates'. Subsidy now goes to developers, lenders and the 1 million private landlords across the UK.

None of it builds the really-affordable, secure and decent homes we need. To win them we need a united movement, combining political demands with mass direct action. Generations before us won council housing, rent control and secure tenancies through rent strikes, protests, marches and occupations. We are learning those lessons in the fight for homes.

\section{Supporters:}

Supporters of The March for Homes include: Defend Council Housing, People's Assembly (London); community campaigns New Era, Focus E15, Fred Wigg \& John Walsh, Our West Hendon; renters campaigns Generation Rent, Hackney and Tower Hamlets private renters; trade unions BECTU and Unite Housing Workers; Disabled People Against Cuts (DPAC), Haldane Society of Socialist Lawyers, Radical Housing Network, Trade Union and Socialist Coalition (TUSC) and the London Green Party.

Film maker Ken Loach, London MPs Diane Abbott, Jeremy Corbyn and John McDonnell, and London Assembly member Darren Johnson supported the January march and a 'student bloc' from London universities joined to add their voice to calls for rent controls and more council housing.

Quotes:

Eileen Short, National Chair of Defend Council Housing, said: 'We took to the street to show the united demand for urgent action. Tenants from all tenures, public and private, campaigns and trade unions are determined to organise together to resist evictions. The growing housing 
movement will not swallow hollow promises and more empty luxury housing. The London Mayor and councils must act now to control rents and invest in council housing.'

Alastair Stephens, People's Assembly (London), said: 'Polls show that most people support rent controls, greater regulation of the private rented sector and a return to the mass building of council housing. Only these actions will solve the housing crisis. These are the demands we took onto the streets on the 31 st of January.' 


\section{Statement Nine}

\section{Title: How do we achieve affordable housing? The role of SMEs}

Author: Rico Wojtulewicz, Policy Advisor, House Builders Association - a division of the National Federation of Builders

Efforts to tackle the housing crisis have uncovered meaningful and complex conversations around the provision of affordable housing. In the City of London, average rent far exceeds mortgage expenditure and many properties bring in higher rent than average wages. Owner occupancy in Britain is the lowest for two decades and those under the age of forty are struggling to find their way onto or up the property ladder.

Over the last three years changes to the planning system have been intended to improve that situation, in part by building family homes and releasing smaller properties to the next generation. However, regionally this has caused some frustrating consequences. In London and the South East, those transition properties have been snapped up by the more affluent and sit accruing rent and property prices have escalated in line with population increase. Thus, much of the region's working population has either moved further from their place of work or they endure wage-swallowing rents.

Outside of London, the situation isn't as catastrophic. Housing isn't swamped by population increase but quality housing is in short supply and family homes are not as readily available in infrastructure equipped areas. Every region in the UK has its unique complications but similar concerns are felt nationwide: high land prices, nimbyism, slow planning decisions, material costs, skills shortages and a lack of financial support. The National Planning Policy Framework (NPPF) has begun tackling the land crisis and has forced identification of these sites for development

but while the viability of those sites is still in question there are larger concerns around infrastructure and making these developments a reality. To tackle that concern, the Community Infrastructure Levy (CIL) has started rivalling section 106 as a means to support community expansion. However, where councils have rushed to identify larger sites they have neglected smaller sites that classically needed SMEs to be developed.

SMEs are integral to tackling our infrastructure concerns; they build on smaller less, attractive sites already in infrastructure-equipped areas. They rarely build enough units to negatively impact localities. They collaborate on larger sites to support housing and social mix. They also build to high specifications and, through the Community Infrastructure Levy (CIL) and Section 106, contribute financially to ease the burdens large sites place on population increase.

The ability for the SME to traverse though planning concerns and deliver a steady stream of homes is a key component to our national house building ambitions, and the versatility of the SME house builder is crucially important in tackling our housing crisis - especially when we consider the variety of business models they provide.

While one SME house builder constructs luxury homes, another places its efforts in affordable housing for first time buyers and growing families. Some build accommodation for the over $55 \mathrm{~s}$ and others build to rent, supporting housing associations, councils or their own business 


\section{Amps}

models. This variety should be regarded as an asset, especially when coupled with an industry desire to employ and train the local population.

The SME house builder is necessary if we are to improve the supply crisis. Yet, while there has been a vast improvement in making sites available, too many of these sites have been earmarked for the large house builders - organisations which build over half our homes and who are bogged down in infrastructure woes. In the 1990s we completed almost 200,000 homes annually and SME housebuilding flourished. Twenty years on and the operational roadblocks to SMEs have seen this 200,000 figure tumble as demand vastly outstrips supply, especially in affordable housing.

For SMEs, access to finance remains a cause for concern and while there has been a motivation to improve the situation, not enough is being done. Allowing local authorities to borrow against their current stock would surely help, but a creative approach to policy needs to count for regional needs. Wales is one place where creative policy has found a platform. Houses into Homes converts empty buildings into homes and investment is supported by a recyclable loan when dwellings are sold or rented. Further financial support has been introduced with the Housing Finance Grant where access to finance builds on social and housing mix in order to stimulate community growth and affordable housing.

Access to finance and land must improve, drastically, but the capacity to develop affordable housing continues to raise questions. How can we tackle the deficiency of bricks? Will large construction projects such as HS2 further exacerbate the skills shortage? What is affordable housing?

The answers will require a lot of coordination but by moving construction opportunities higher on the political and educational agenda we can ease these complications and allow new inevitable industries to flourish. As well as employing locally, the SME is a proponent of new industry. Solar PV tiles have become more popular, ground and air source heating is a real consideration, high efficiency fabrics are standard and material variety is challenging our current rationale on energy efficiency. The determination of the SME to look to new industry when building homes points to a direction we will inevitably follow. Their generous contributions to section 106 should make houses affordable over their lifetime and not just their purchase price - our incredibly innovative green industry would also benefit.

Without openly and honestly looking at the factors stifling supply we cannot tackle the housing crisis or make homes affordable. Through responsive policy and infrastructure planning we can make a start but without unified political backing we will struggle to tackle unaffordable housing and unaffordable living.

The National Federation of Builders seeks to be the influential voice for construction, creating the environment for business to thrive and contribute to the success of the UK economy. Its mission is to promote the building profession and influence the business environment to provide optimum conditions for successful building.

The House Builders Association is a division of the National Federation of Builders. It has over 600 house builders in its membership and, since its launch in 2006, has established itself with government and the media as the voice of the small and medium-sized house builder. 


\section{Statement Ten}

\section{Title: Building the Homes We Need}

Authors: Campbell Robb CEO, Shelter; Marianne Fallon, Head of Corporate Affairs, KPMG in the UK

\section{Open letter to Dear David Cameron, Nick Clegg and Ed Miliband:}

Everyone now accepts that we have a desperate housing shortage in England. Each year we build 100,000 fewer homes than we need, adding to a shortage that has been growing for decades. What's more our current house building system seems incapable of delivering growth on the scale required. Growing demand means that without a step change in supply we will be locked into a spiral of increasing house prices and rents - making the current housing crisis worse.

Despite modest efforts to improve supply over many years, there has been no comprehensive plan to get us rapidly building the homes the country needs. If the next government shies away from showing the strong leadership needed, having a home of your own to rent or buy affordably will become a distant dream for an increasing number of people in this country. Rents will rise and homelessness will increase. The economic recovery will be held back by high housing costs, an immobile workforce and unstable housing markets.

In short, the country needs a serious plan to transform housing supply. One that faces up to tough choices, but also sets a new tone for political generations to come - and all parties need to sign up to it. Solving this problem will take leadership and vision from across the political spectrum at local and national level. All parties share responsibility for the housing shortage, and all must commit to ending it.

KMPG and Shelter have put together a comprehensive, visionary programme for the next government to get the country building the homes it needs. Taking steps to lower the cost of land for development will reduce the profits made by some land owners, but allow better homes to be built and stimulate a new wave of SME builders who have been squeezed out of the market. Increasing investment to build genuinely affordable homes will mean tough fiscal choices, but reducing the cost of housing will also cut the welfare bill. Introducing new taxes on unused housing land and empty homes will be unpopular with some, but will get development moving on stalled sites.

There are no easy solutions or silver bullets. Coherent and co-ordinated action is needed at each stage of the development process, to deliver a new vision in the way that housing is provided in England. Our report, Building the Homes We Need - a Programme for the 2015 Government has been written through close collaboration

between housing policy, financial and housing market experts in KPMG and Shelter. It draws on a wide range of expertise and new research to address the problems and propose solutions. We are confident that our programme will create the new generation of homes which are so desperately needed. We look forward to working with you to deliver it. 


\section{Statement Eleven}

\section{Title: A home is a human right}

Author: Siân Errington. Research Officer, Unite the Union

That the housing crisis is complicated shouldn't be an excuse to not take action. It is a basic human right that everyone has a decent, warm home that they can afford with security for the future. Yet in $21^{\text {st }}$ Century Britain a home is becoming an ever more precious commodity young people are being priced out of having their own home with over a quarter of 20-34 year olds living with their parents. When we asked Unite young members we found that $86 \%$ of our members under 25 years old were living with their parents with the rest renting privately or in a house share. The removal of Housing Benefit for these young people will only make this situation much worse. It hinders the ability to live independent lives and for those who, for whatever reason, do not get on with their parents, and the removal of Housing Benefit just adds more barriers to finding a more suitable home. It's not just young people affected by the housing crisis however. Tackling the housing crisis is a win-win for everyone: it brings with it multiple economic and social benefits. There is an urgent housing need in Britain - and we need action to tackle it. Here are some of the things Unite believes should happen:

End the housing shortage .

We need to build at least 240,000 additional homes a year just to keep up with the new households that form each year - and there is a large backlog because we have been underbuilding for years. If we don't address this root cause then house prices and private sector rents will continue to soar away as the housing shortage keeps getting worse in the years and decades to come.

1) We should build at least 1 million new homes - public investment for a large scale council housing building programme. !

- Not only does building homes address the desperate need but, for every $£ 1$ spent on housing construction an extra $£ 2.09$ is generated in the economy, and it creates a direct saving in future tax and benefit payments for the government!

- We must direct investment by central government to local councils so that they can build in the most straight forward, practical and efficient method for stimulating provision. We've had years of house building being left to the private sector. Our housing market is broken and the severe housing shortage is the result.

- As well as providing more direct central funding from government, we can lift the borrowing cap for local authorities so that they can borrow to invest in homes.

- If we are to address the huge national shortfall in home building we need regional home building targets that ensure that rural areas benefit from social housing builds, as well as our urban centres.

2) End the automatic 'Right to Buy' - we need to dramatically increase the number of council homes 


\section{Amps}

- Because of the ConDem government policies 35,000 homes for those on low incomes were lost in one year. At the same time there are over 1.3million households on the social housing waiting list in England alone. Unite think that as well as building more homes the 'Right to Buy' council homes should end full stop. But at the very least we can all agree that councils should not have to operate the policy, so that where a local Council has got a housing shortage the elected representatives can decide to suspend 'Right to Buy'. It is not enough that one new council home is built for each one that is lost under 'Right to Buy'. We need to increase the number of council homes. Scotland has already suspended the Right to Buy and Wales is considering it.

- The demolition of structurally sound council homes that could be brought up to decent homes standard and in which communities want to continue to live must end.

\section{A home you can afford}

House prices and private rents have soared away - if a pint of milk had risen as much as house prices over the past 30 years it would cost $£ 10.48$ ! The National Housing Federation has forecast that without any control private rents will rise by another $35 \%$ by 2020 - much more than wages are predicted to grow.

Already More than 4 million private renters live in poverty and, on average, private renters spend a whopping $40 \mathrm{p}$ out of every $£ 1$ they earn on their rent. But the private rented sector is in a worse condition and costs over $£ 20$ more a week in Housing Benefit than the social rented sector - the difference equates to more than $£ 1.8$ billion a year.

The solution isn't to punish tenants by cutting their Housing Benefit - and it is not to carry on with public spending increasingly funding private landlords who want to charge spiralling rents into the distant future.

3) Introduce rent controls in the private rented sector to stop people being priced out of their home - and end rip off letting fees!

- The maximum that rents should increase by each year should reflect, and be linked to, people's ability to pay. For example, by linking it to average wage growth or the 'cost' of housing.

- Legislate to end letting fees - tenants should not be charged with the cost of setting up their tenancy.

4) Housing benefit should be available to all adults living in Britain and set at an appropriate level.

- Housing Benefit should be available to all adults living in Britain; the Bedroom Tax abolished, the benefit cap removed, and the cuts from the changes to the Local Housing Allowance and the non-dependent deductions reversed. Households should not be punished for spiralling housing costs caused by successive governments' failure to build homes. The Housing Benefit cuts by the ConDems have hit well over 1 million households 


\section{Amps}

and have drained $£ 2,745$ million out of our economy! The Housing Benefit cuts are contributing to the social cleansing of our inner cities and risk entrenching people who do not know their rights, or cannot afford decent housing, into dangerous, poor and illegal living conditions. Despite the 'scrounger' rhetoric about benefit claimants, three-quarters of new housing benefit claimants are people in work. They need help because soaring housing costs have outstripped stagnant wages.

\section{Decent homes for all}

An estimated 660,000 households in England are overcrowded. It occurs most in the social and private rented sectors. In October 2014, 1-in-10 private renters in England reported that they had suffered ill health in the past year because of the poor state of where they live, with many saying they had problems with mould and damp, electrical hazards and pest infestations. We have one of the least regulated private rented sectors in Europe -and a proliferation of poor housing that costs is the result.

As well an unacceptable number of homes being in a poor state, nearly three-quarters of private sector landlords are private couples or individuals, with half of all landlords owning fewer than five properties - and anyone can become a landlord if they have the money. Many may simply not be aware of their obligations to tenants - as well as being inclined to increase rents to improve their return. But there are also plenty of examples of exploitative private landlords that tenants should not be at the mercy of.

5) Everyone should have a decent home - that means it should at least be free from damp, be well insulated and warm, safe, pest free and not overcrowded

- Investment in a national, council-led programme to provide basic insulation measures to the 10 million homes without cavity wall insulation and full loft insulation would create jobs, create warm homes and reduce fuel poverty - it is better for the environment and people.

6) Private landlords should be registered and licensed to ensure decent homes, minimum standards and tenants' rights are respected

- Scotland already has a register for private landlords which has a 'fit and proper persons' test, and Wales is introducing one this year. There should mandatory registering and licencing of private landlords, administered and enforced by the relevant local authority which contains: a 'fit and proper persons' test; ensures that decent homes standards are met and maintained; that tenants' rights are respected; and helps prevent 'revenge evictions'.

A secure and stable home for the future

The ending of an assured short hold tenancy in the largest cause of homelessness recorded by local authorities, with half of tenants in the private rented sector have a tenure of 1 year or less. While the argument put forward is that these contracts offer flexibility for people who are very mobile, the truth is that for an increasing number of people, couples and families who want to settle down, 
'flexibility' simply means insecurity, and a barrier to making long term plans in a home or a local community. The private rented sector is now the second largest type of housing provided in the UK.

7) Restore security of tenure to the social rented sector, and introduce it in the private sector we need longer term lets.

- Restore security of tenancy in the social rented sector and legislate to provide longer term lets of 3 to 5 year tenures in the private rented sector.

- There is a growing evidence that 'revenge evictions' where tenants are evicted by their landlord after complaining about the state of their accommodation or a landlords (in)action. Landlords should not be able to issue no fault eviction notices if they have failed to meet safety standards or a tenant has lodged a complaint with the local authority in the past year.

\section{Supporting Housing Support}

Creating homes for everyone who needs them, and ensuring that tenants and residents rights are respected, means that some people will need extra funding or support to enable: independent lives; that everyone who needs it has access to housing advice and legal support; and that homes and estates are maintained to a decent homes standard.

8) Everyone should be enabled to live independently, and feel at home in their home

- Restore the ring-fence to 'Supporting People' - funding given to local Councils by central government to provide supported housing to enable older and disabled people to live independent lives and ensure it is funded properly so it can do the job it needs too. The ring-fence was removed by the ConDem coalition and local authority services have been hit extremely hard by the programme of public spending cuts and austerity.

- Restore the Independent Living Fund for disabled people.

- The programme of austerity has had a devastating impact on local authority services such as social care and occupational health services that can make the adaptations to homes that some people need to continue to live in them. There is an alternative to austerity and these cuts don't have to be made.

9) Improve accessibility for Legal Aid for those facing eviction and other housing problems

Legal Aid for those facing evictions is means-tested and the funding pot has been severely cut causing a decrease in the numbers of organisations that support people. It has left some areas with no legal aid practitioners who can support people in challenging evictions or dealing with other housing problems. Unite is part of the Justice Alliance which has opposed cuts to Legal Aid and reducing the scope of what people can claim Legal Aid for.

- Expand the scope of Legal Aid provision to include Housing Benefit entitlements and to support tenants taking action against disrepair. 


\section{Amps}

10) No privatisation of our housing and support services and ensure housing workers receive decent pay, terms and conditions

- The delivery of housing support, advice services and maintaining a decent homes standard requires a well-paid and trained workforce. Where possible bring repairs and maintenance services back 'in-house' and end further transfers of housing stock away from councils with no privatisation of Housing Associations. 


\section{Statement Twelve}

\section{Title: Affordable Housing: An Economic Perspective.}

Stewart Baseley. Executive Chairman, The Home Builders Federation

All the key indicators are predicting continuing increases in house building output in 2015.

The National House Building Council (NHBC) latest statistics showed that in the three months to November, private sector reservations were up 19\% on the same period 2013 whilst our own latest Housing Pipeline report showed the moving annual total of plots consented continues at just below the 200,000 level from a trough of only 115,000 in 2011. Both of these are strong indicators of future supply levels.

Clearly, though, our industry's ability to convert these permissions into starts and then homes people can live in will depend on a complex number of determinants. We can never be immune from, or necessarily predict world events. But that accepted, economic stability and housing policy certainty are essential to allow businesses to plan properly for sustainable growth. The rise in demand for new homes has been largely due to increased consumer confidence and a more active mortgage market, on the back of an improving economy, and of course the Help to Buy Equity Loan scheme.

The big event of 2015 is of course the general election. All the major parties now accept that we have an acute housing crisis and are committed to increasing the number of homes built with a particular emphasis on helping young people onto the housing ladder. The debate from a housing perspective is about the different approaches the parties would adopt to achieve the increase in supply they all seek.

All three main parties recognise the need for schemes to assist buyers - the success of Help to Buy Equity Loan and its contribution to the recovery would make it difficult for anyone to argue otherwise. In its first 20 months, to the end of November, the scheme had been used to purchase more than 38,000 homes, helping to create almost

32,000 first-time buyers in the process. The Coalition has already announced an extension of the Equity Loan scheme to 2020 and has also proposed a new Starter Home scheme whereby first-time buyers will be purchase new build homes at $80 \%$ of market value. The Labour Party has suggested that they would maintain Help to Buy Equity Loan, albeit with tweaks, possibly with regards to the maximum purchase price.

The important point for our industry is that the scheme exists until such time as the mortgage market recovers and high loan to value products are generally available again. The certainty that the scheme will be around until 2020 allows us to invest in skills, land and increasing our capacity, and thus play our part in increasing output.

However it isn't just about help for people to buy. We also need to see further reform of the planning system to speed up the rate at which applications are processed. The current Government accepts the need to act. We made a number of proposals last summer on ways to 


\section{Amps}

speed up and simplify the end-to-end planning process and we were pleased to see several of our suggestions earmarked for further work in December's Autumn Statement. Whoever is in office after May 7th simply has to find a way of speeding up the current system if land supply is to meet housing demand.

Labour's position on planning is inevitably more uncertain as their policies are still being formulated and we still await confirmation of which of Sir Michael Lyons' largely very sensible recommendations they are to adopt. Sir Michael's report included some ideas with regards to the Homes and Communities Afency (HCA). I have always believed that the HCA works best when it is focused on delivery. We need to ensure this approach continues. Since its creation in 2008 the HCA has more often than not been in a state of flux. However, its administration of the Help to Buy scheme has been exemplary. In addition, we are now working with both the HCA and government to help to simplify and accelerate the disposal of surplus public sector sites, which the Agency will take the lead on for most of central government land from April.

Department of Communities and Local Government, (CLG) charging schedules are a major concern. The Community Infrastructure Levy (CIL) must be set at sensible, realistic levels and there must be transparency about how CIL money is spent. Otherwise it will become a barrier to housing delivery. Actions are also required to assist getting more smaller builders building again something all parties are seemingly agreed on. Last month, for instance, the government concluded its consultation on a small sites exemption for the off-site elements of the zero carbon standard.

As well as more support for development finance initiatives, councils could do more by bringing more smaller sites forward, reversing the trend towards planning authorities allocating few very large sites which are usually out of reach for smaller developers. Some indications suggest we will see an increase in interest rates later in the year. Clearly this would have implications for affordability for homebuyers, and thus for house builders, and so must be seen as a potential threat. But as the Governor of the Bank of England has been at pains to stress, assuming the economy remains on course, increases will be gradual to ensure they don't threaten the improved wider conditions. With the recovery still in its infancy, and build levels still a long way from where all politicians are agreed they need to be, it must be hoped that as the year progresses, decisions are made that encourage long-term, sustainable increases in supply. If they are, then the positive indicators we entered the New Year with should solidify into more new homes. 